\title{
School Leadership and Citizenship Education: The Experiences and Struggles of School Party Secretaries in
}

\section{China}

\author{
Shuqin Xu, Sun Yat-sen University, China \\ Wing-Wah Law, The University of Hong Kong, China
}

\begin{abstract}
Many scholarly works have examined school leadership, and many others have studied models for teaching citizenship education. Research combining both school leadership and citizenship education, however, is rare. The leadership of China's school party secretaries (SPSs), who are the equivalent of school principals in the Chinese school system and are particularly responsible for leading and supervising citizenship education and political work on campus, is even less researched. Drawing on data from document analysis and interviews, this empirical study investigates the dynamics and complexities of SPSs' school leadership. The findings reveal a complex division of power and labor between SPSs and principals, as well as the SPSs' struggle to balance state control with their professional autonomy and their power struggles with principals over leadership in citizenship education. The findings also show that, in China, the SPSs' leadership in citizenship education is a form of political leadership that seeks to implement the state's policies and transmit state-prescribed values. In addition, it is conducted in a socio-political context characterized by the integration of administration and politics. Moreover, it involves complex relationships and interactions with higher authorities and principals with diverse interests. Finally, this study presents theoretical implications for understanding school leadership in citizenship education.
\end{abstract}

Keywords School leadership $\cdot$ Citizenship education - School party secretaries - Educational governance $\cdot$ China

\section{Introduction}

Considerable research has been conducted on both school leadership and citizenship education. Numerous studies have proposed school leadership models and have examined school leadership styles and successes, principalship and social changes (Hoy and Miskel 2004; Dimmock and Walker 2002). Others have examined the meaning, functions and pedagogies of citizenship education (Kennedy et al. 2010; Banks 2008) and have suggested citizenship education models in response to social changes, such as globalization (Osler and Starkey 2003; Kubow et al. 1998). However, how school leaders exercise their leadership in citizenship education is under-researched. Similarly, despite numerous studies on both school leadership (Bush and Qiang 2000; Law 2009) and citizenship education (Zhao and Fairbrother 2010; Lee and Ho 2005) in China, studies on school leadership in relation to citizenship education are rare. 
With reference to Shanghai, China, this empirical study investigates the dynamics and complexities of the role played by school party secretaries (SPSs - the de facto equivalent of school principals) in leading and supervising citizenship education. Unlike most countries, in China, schools feature two intertwined leadership lines - political and administrative. Each school normally has an SPS who is responsible for political work on campus, including citizenship education, and a school principal who is responsible for overall school administration. The current study explores the SPSs' relationships and interactions with higher authorities and principals in leading citizenship education. In addition to document analysis, interviews were conducted in 2011 to solicit the views of SPSs, principals, deputy principals in charge of citizenship education (DPCEs) and heads of citizenship education departments (HCEDs).

The study found three main patterns of the SPSs' leadership in citizenship education: leading without a clear division of power and labor with principals; leading through mediating between higher authorities and the school; and leading by cooperating and competing with principals. The SPSs' leadership is a political exercise designed to implement the Communist Party of China's (CPC's) policies and transmit CPC-prescribed values on campus. These patterns can be seen as a result of the complex and dynamic integration of educational administration and politics in China. Challenges confronting SPSs and school leaders' are individual factors in these patterns.

This article first reviews extant literature on school leadership and citizenship education to provide a general background of school leadership in China. Second, it describes the design and implementation of this study. Third, it presents the study's major findings regarding the patterns of SPSs' relationships and interactions with higher authorities and principals. Fourth, it suggests explanations for these patterns, and then discusses theoretical implications for understanding school leadership in citizenship education. Finally, it presents the study's conclusions and limitations.

\section{School leadership and citizenship education}

Citizenship education has long been an important curriculum area and education research subject, and school leaders, as Remy and Wagstaff (1982) have pointed out, are expected to play an important role in it. Citizenship education socializes students by equipping them with the knowledge, skills and values necessary to develop their civic consciousness and agency, so they will function and live as good citizens (Banks 2008) and contribute to economic and political development (Kennedy 1997). Research on citizenship education has covered various areas, including curriculum (Kerr 1999), pedagogy (Kennedy et al. 2010), and assessement (Pike 2007). Various models have suggested how and why citizenship education can respond to and accommodate social change (such as globalization), including multidimensional (Kubow et al. 1998), multicultural (Banks 2008) and cosmopolitan (Osler and Starkey 2003) citizenship education models.

However, relatively few studies have examined the relationships between school leadership and citizenship education. As Remy and Wagstaff (1982) have noted, principals can exercise leadership in citizenship education by leading curriculum and instruction; developing school organization and culture; and cultivating relationships among schools, teachers and the community. Such studies, however, have not explained the complex relationships and interactions between school leaders, their subordinates and the government in the implementation of citizenship education at the school level. These inadequacies are only partly supplemented by the literature on school leadership.

Studies have shown principals' various approaches to school leadership - including instructional, transformational, transactional and distributed leadership (Smith and Piele 2006) - and how these affect 
their relationships with teachers, students, parents, the community and the government. In addition to personal leadership styles, school leadership can be affected by internal and external factors. The former includes subordinates, organization, school structure and culture, while the latter includes community composition and expectations, the government, political parties and the society in which the leadership is exercised (Hallinger and Muppy 1986; Walker and Dimmock 2002).

Principals are expected to cope with internal and external stakeholders, particularly those with the power to allocate scarce resources or to make decisions. According to the political leadership model, schools are considered political arenas in which school leaders exercise political leadership by managing the politics among different stakeholders, employing strategies to meet and balance diverse expectations and interests, and managing conflicts to reach commonly agreed upon goals (Lashway 2006). As such, Lashway (2006) has contended that school leaders' political leadership must address both macro- and micro-politics. Macro-politics relates to the school's external environment and its relationships and interactions with external stakeholders, including teachers' unions and governments (Blase and Blase 2002). Micro-politics refers to internal stakeholders' use of formal and informal power to advance their interests, purposes and preferences and to influence organizational affairs (Blase and Anderson 1995). School-level micro-politics involves principals, teachers and students (Lashway 2006), and they can actively react to, rather than be passively framed by, macro-politics (Hoyle 1999; Lashway 2006). School leadership thus involves interpreting, implementing, ameliorating and modifying macro-political directives and influences, and aligning micro- and macro-political forces (Lashway 2006).

The political leadership model has been mostly used to analyze the micro-political relationships between teachers and principals, other teachers, students and parents (Blase and Anderson 1995), and to promote school reform (Datnow 2000), educational change (Bush 2011) and instructional improvement (Blase and Blase 2002). Although the political leadership model focuses on principals' leadership and helps dissect the SPSs' leadership in citizenship education in China, it has not been applied to leadership in citizenship education specifically.

While there is much literature on education and school leadership in China, little specific attention has been paid to the SPSs' leadership in citizenship education. Chinese school leadership is situated in a dual leadership system composed of parallel administrative and political lines headed by principals and SPSs, respectively (Xiao 2000). Some studies have found that, unlike principals, whose primary focus is administration, SPSs occupy positions that are politically motivated and defined (Lin 1993). In addition, SPSs are charged with strengthening the CPC's leadership and ensuring that schools remain politically aligned with the party (Xiao 2000).

The dual school leadership system was established by the CPC following its rise to power in 1949 . This system has engendered a complex relationship between school leaders (generally principals and SPSs) and the CPC-led state (the most influential macro-political actor in China), which has been described as using control/passive obedience and control/ active response models. The former holds that Chinese school leaders fully follow and obey the CPC-led state's wishes and dictates (Child 1994); the latter points out that, despite being state-controlled, school leaders can play an active leadership role by analyzing and responding to that control in ways that maximize their and their schools' interests (Law 2009, 2012). At the school micro-political level, Tao, Liu and Yi (1988) have described the relationship between principals and SPSs as cooperative, while other Chinese scholars (e.g., Lin 2000) see it as an institutionalized power struggle. However, few studies have explored how SPSs simultaneously interact with the CPC-led state and principals, especially in leading citizenship education. 
The CPC-led state places great emphasis on citizenship education in China, variously describing this political socialization project in Chinese schools as ideo-political education, moral education, patriotic education and citizenship education (Law 2006; Zhong and Lee 2008). Despite these different descriptors, citizenship education in China, as has been observed by a number of researchers (e.g., Law 2006; Lee 1997; Zhao and Fairbrother 2010), is still an ideological instrument for transmitting the political doctrines and positions of the CPC-led state and cultivating values that encourage students to be patriotic and supportive of its leadership in a quest to foster a modern Chinese socialist citizenry. Before the 1970s, the CPC-led state predominately used citizenship education to cultivate proletarian consciousness, faith in socialism and loyalty to the CPC and Chairman Mao among students. In the post-Mao era, beginning in the late 1970s, Chinese citizenship education has become more responsive to and accommodative of changes in domestic and global contexts. For example, it has placed more emphasis on students' personal and psychological growth, blurred ideological distinctions between capitalism and socialism, and incorporated common global concerns (e.g., terrorism and the environment) into its curriculum (e.g., Lee and Ho 2005; Zhu and Feng 2008). Despite having updated citizenship education to cover topics on global, national, local and individual levels, the CPC-led state has remained the key actor in the selection and translation of the elements of citizenship education. In addition, it has consistently emphasized national elements (Law 2006) and has limited individual development within the country's political and legal framework to highlight the socialist nature of the state (Cheung and Pan 2006).

Both the general literature and Chinese studies on school leadership and citizenship education have shed some light on the SPSs' leadership in citizenship education in China; in particular, the concept of micro- and macro-political factors is useful for analyzing the complex contexts in which SPSs exercise their leadership. However, neither body of literature has explained the complex relationships among SPSs, principals and the CPC-led state regarding school leadership in citizenship education in China. Specifically, the studies do not reveal how SPSs balance state control and their own professional autonomy over citizenship education, nor do they explain the complex tensions between SPSs and principals caused by the ambiguous nature of citizenship education.

\section{School leadership and citizenship education under the domination of the CPC-led state}

Since its founding in 1949, China, a country of 1.3 billion people spread over 31 mainland administrative areas, has been ruled by the CPC. The country's development and nation-building under the CPC's leadership can be divided into two stages - one featuring an ideological emphasis on class struggle (the Mao Zedong era, 1949-1976), and one stressing economic modernization and the opening of China to the world (beginning in the late 1970s). This section introduces how the CPC-led state has controlled Chinese school leadership and has complicated school leadership in citizenship education in order to consolidate and sustain its power and leadership position as the most powerful macro-political actor in China.

Since coming to power in 1949, the CPC-led state has used various measures to control education, including exerting control over school leadership. As introduced in the previous section, it has replicated China's state governance model, which features political and administrative institutions at each level of the state. At the school level, a dual school leadership system has been established, headed by the SPS and the principal. These two leaders are required to follow the political and administrative leadership of higher authorities to ensure and enhance the CPC's leadership and control over schools (Li and Wang 2000). The state-mandated internal school leadership system consists of several principal-led administrative departments (teaching, citizenship education, general office, grades and classes) while 
SPS-led political departments consist of the school party organization, teacher congress, the Communist Youth League (CYL) and the Young Pioneers of China (YPC). Moreover, the CPC-led state designed the administrative and political lines to be inter-connected: a principal may also be an SPS, while a principal who is not also an SPS must support the SPS, and vice versa (State Education Commission 1990). The teacher congress (under SPS leadership) monitors the principal's work, and the CYL and YPC, while part of the political line, contribute to the citizenship education department in school.

China's domestic history since the 1950s has shown that the distribution of power between SPSs and principals has been affected by changes in the political climate and by CPC policies on education and school leadership (Bao 2004). Specifically, when the CPC faces political crises or focuses on ideological issues, schools emphasize political development and thereby give the SPSs more power. On the other hand, when the CPC stresses economic modernization and development, schools are directed to focus on academic development, thus giving the principals more power (Zhang 2006; Xiao 2000).

During the period of economic recovery between 1952 and 1957, the CPC-led state introduced the Principal Responsibility System (xiaozhang fuzezhi, PRS) to enhance principals' power and enable them to focus on academic development and to cultivate, among the student population, the talents needed for China's socialist modernization (Xiao 2000). The anti-rightist movement (1957-1976), with its state-led emphasis on political reconstruction, restored power to the SPSs and changed the school leadership structure by putting the PRS under SPS control (Chen 2003). However, this was criticized for giving SPSs too much power and for obscuring the distinction between party and administrative works (Xiao 1984).

To rectify this, and to ensure that the Chinese people were "well-educated, technically skilled and professionally competent," and thus capable of driving China's economic and social progress in the 1990s, the CPC Central Committee (1985) reformed the PRS, giving principals full responsibility for their schools and requiring school party organizations to "abandon the practice of monopolizing the management of everything." In addition to reducing CPC influence on and interference in school administration, the post-1985 PRS divided power and responsibilities between the schools' political and administrative leaders. Under the guidance of educational authorities, principals are now expected to be their school's decision-maker, in addition to being in charge of all administrative affairs on campus and bearing all related legal responsibilities. On the other hand, SPSs are mainly responsible for their school's political work, including the development of school party organizations and ideological work (Communist Party of China Central Committee 1985).

Under the revised PRS, the relationships among the CPC-led state, SPSs and principals are complicated. The CPC-led state controls all key aspects of the school leaders' work and career paths, including their leadership goals and their school's direction, as well as their recruitment, training and promotion (see more in the Discussion section). Moreover, the labor and power distribution between principals and SPSs is still not clearly divided. According to PRS policy, SPSs are major political actors - as the CPC's secretaries at the school level, they are theoretically powerful enough to monitor principals and support school administration through their political work (Communist Party of China Central Committee 1985). However, principals have been given the final say on key school decisions as well as control over school personnel and finance, the two major areas in which leaders can demonstrate their power.

The complicated relationships among the three political actors are also revealed in the SPSs' and principals' roles of leading citizenship education. The CPC-led state has made both principals and SPSs responsible for leading citizenship education and making it a school priority. However, since the revision 
of the PRS in 1985, principals have been given full responsibility for citizenship education and more power over its implementation, while the SPSs have been restricted to designing citizenship education plans, unifying school organizations to work for citizenship education and cooperating with principals on citizenship education (Teng 1988). Although the principals' and SPSs' responsibilities in citizenship education are divided, they are also interconnected (Ministry of Education 1998). Whereas SPSs supervise principals' leadership in formal curricula of citizenship education instruction, both principals and SPSs are responsible for informal curricula of citizenship education.

\section{The study}

\subsection{Research purpose and questions}

This empirical study aims to investigate how schools' micro- and macro-politics facilitate and constrain SPSs' leadership and professional autonomy in citizenship education through the following three research questions:

1. How do SPSs respond to their responsibilities in leading and managing citizenship education?

2. How do SPSs and principals share responsibilities and tasks in leading citizenship education? How do they work with each other and why do they act as they do?

3. In what ways and by what means do SPSs lead and manage citizenship education?

\subsection{Research methods}

While China is vast and diverse, this small-scale study adopted Shanghai as its data collection fieldwork site because it was the birthplace of the CPC in 1921, and it is one of China's most economically and culturally advanced areas. More importantly, Shanghai is often ahead of other areas of China in instituting citizenship education reforms and school leadership. In 1984, Shanghai was one of the cities chosen to pilot the 1985-PRS in its schools (Sun et al. 1988). Moreover, it proposed, and in 1993 became the first city to pilot, the Principals' Professional Ranking System (xiaozhang zhijizhi), which delinked the principals' rankings from those of government officials, instead tying them directly to professional qualifications. Shanghai fully implemented this system in all of its schools in 2001 (Jin 2001) and introduced similar changes concerning the SPSs' rankings in 2003 (Shanghai Municipal Education Commission 2003). In 2012, the Ministry of Education promoted Shanghai's professional ranking model for principals across China (Jiao 2012). For similar reasons, other researchers have also chosen Shanghai to investigate reforms to citizenship education (e.g., Lee and Gu 2004) and school leadership (e.g., Wong 2005).

The current study adopted two main data collection methods: document analysis and interviews. To understand the history and development of the SPSs' tasks and work, the study reviewed official and school policy documents on citizenship education, school leadership and the SPSs' on-campus duties. Document review, as Merriam (1998) has suggested, provides context for scholarly research.

In addition, the study conducted semi-structured interviews with SPSs and their citizenship education co-workers (including principals, DPCEs and HCEDs). The goal of these interviews was to record the SPSs' thoughts and interpretations as they relate to the research questions, clarify the data received through in-depth probing (Wiersma 2005) and allow informants to elaborate on their responses or to explore unanticipated topics or comments (Merriam 1998). The interviewees were each asked to: (a) identify and explain the influence of higher authorities on school leaders; (b) interpret the SPSs' and principals' working relationship regarding citizenship education; and, (c) interpret the strategies SPSs 
use in leading citizenship education. Because of their different roles and perspectives, the interviewees provided multiple and triangulating information on the SPSs' relationships and interactions with other stakeholders in school leadership and citizenship education. Interview questions fell into two major categories. The first category focused on general questions that all the informants were asked to answer (e.g., What are the functions of citizenship education? Could you familiarize me with your school's citizenship education program? What are your responsibilities in citizenship education?). The second category focused on specific questions that were based on the informants' post. The SPSs who were not principals, and vice versa, were asked questions such as, "What are the similarities and differences between you and your principal's/SPS's responsibilities in citizenship education?" and "Could you give me some examples to show how you and your principals share responsibilities?" The SPSs who were principals were asked questions such as, "How do you deal with the relationship between school administration and political work?" and "Could you give me some examples?" Finally, the DPCEs and HCEDs were asked questions such as, "How do your SPS and principal divide responsibilities and power in leading citizenship education?" and "How do you divide yours with them?"

Between March and June 2011, the study selected informants based on direct contact with school leaders, guidance from local experts in Shanghai and snowball sampling (i.e., existing interviewees recommending other interviewees) (Merriam 1998). In total, 44 school leaders from 24 Shanghai schools were interviewed: 15 SPSs, including three who were also principals; 13 principals; four DPCEs who were not SPSs; and 12 HCEDs. Eight of the SPSs interviewed had been an SPS for less than five years (as of 2011), five for between five and ten years, and two for more than ten years. Of the interviewed principals, three had been a principal for less than five year, six for between five and ten years, and four for more than ten years. Of the interviewed HCEDs, six had been an HCED for less than five years, five for between five and ten years, and one for more than ten years. Two of the DPCEs had had their position for less than five years and the other two for between five and ten years. Three strategies were used to unearth subtle issues during the interviews. First, the school leaders interviewed were invited to introduce their career experiences and school citizenship education programs, which provided a basis for asking their views on the tensions and complexities involved in leading citizenship education. Second, they were asked to provide examples to clarify their opinions. Third, triangulation was facilitated by asking the interviewees to comment on subtle issues which were mentioned in their school documents or raised by other interviewees.

The interviews were conducted on an individual basis, mostly in the interviewees' offices, and lasted one hour on average. The interviews were audio-recorded with the permission of the interviewees and were later transcribed verbatim to facilitate analysis. NVivo software was used to analyze the interview data (Bazeley 2007). Special attention was paid to the SPSs' relationships and interactions with higher authorities and principals, as well as the strategies they used to lead citizenship education and others' interpretations of those strategies.

\section{Major findings}

The study found three main patterns in the SPSs' leadership in citizenship education: a complex division of power and labor between SPSs and principals; mediation by the SPSs between higher authorities and schools to balance state control with their professional autonomy; and collaboration between and contention for power among SPSs and principals over school leadership in citizenship education. 


\subsection{Division of power and labor between SPSs and principals}

The first pattern relates to the SPSs' authority and responsibilities in school. All SPSs and principals interviewed noted that the 1985 reintroduction of the PRS required principals to be responsible for school administration, including citizenship education, instruction, physical and art education, school labor work, finances and safety, staff welfare and parent relations. Meanwhile, the SPSs were tasked to focus on campus political work, monitor and support principals' work, recruit and cultivate school CPC members and direct staff/student political education.

Despite this structural distinction, it is difficult to define clearly the SPSs' and principals' authority and responsibilities for general school leadership. In separate interviews, SPS3, SPS12, P3 and P7 described administration and political work as "inseparable" (dangzheng bufen), while SPS3 and SPS8 noted that their work directly concerned instruction, which was the principals' main responsibility. SPS2, SPS3 and SPS8 linked school party work to instruction in three ways: through the design of party activities (e.g., devoting staff political study time to instructional issues); by recruiting outstanding teachers to become party members; and by asking teachers who were party members to make positive contributions to instruction.

Similar ambiguity was found regarding citizenship education. As expressed by some school leaders interviewed (e.g., SPS4, SPS7 and P10), principals bore "primary responsibility for all work on citizenship education, with the monitoring, support and cooperation of SPSs." Meanwhile, SPSs observed citizenship education classes, organized competitions between teachers to promote political themes in teaching, and led and managed CYL and YPC, political student organizations for the recruitment and training of future CPC members. Other interviewees (e.g., SPS1, SPS6 and P7) saw the division of authority and responsibility between SPSs and principals in citizenship education as "vague." For example, both SPSs and principals had to "carry out all the CPC's policies of citizenship education" (e.g., SPS1 and SPS7) and "ensure that their schools were guided by the CPC's ideology" (e.g., SPS1, SPS8 and SPS12). In addition, their citizenship education leadership duties often "overlapped"; for example, although principals were responsible for human resources, they relied on SPSs to cultivate, guide and appraise citizenship education teachers.

\subsection{SPSs as mediators between higher authorities and schools}

The second pattern identified in the SPSs' leadership in citizenship education concerns their mediating role between schools and higher authorities. The SPSs were subordinates of and reported to the CPC-led state yet they were also school leaders, responding to and interpreting government policies and instructions to suit multiple political actors' needs. The SPSs' mediating role can be seen through their responses to and interpretations of CPC-prescribed values regarding citizenship education.

\subsubsection{The dilemma between upholding the CPC's political values and promoting students' individual development}

All of the SPSs interviewed asserted that their leadership in citizenship education highlighted the CPC's political values (e.g., love for socialism and the CPC, patriotism, Chinese history and culture, unity among Chinese ethnicities, and dedication to the nation and fellow citizens), which were "the goal and core of citizenship education" (SPS19). Political values were stressed in citizenship education to guide students to "pay back to and serve national needs and national development, [and] defend national dignity 
and independence" (SPS1 and SPS13). According to the interview findings, SPSs employed four main government-prescribed strategies to implicitly and explicitly foster the students' socialist political values: establishing a favorable school ideological environment; organizing, and encouraging students to attend, extra-curricular citizenship education activities; developing school-based citizenship education curricula; and monitoring and encouraging citizenship education instruction and its penetration into other subjects.

Despite recognizing the importance of political education, the SPSs and principals interviewed insisted that, from a school perspective, citizenship education should foster the students' individual development before addressing more abstract political ideology. Many SPSs interviewed (e.g., SPS5, SPS11 and SPS13) stated that citizenship education should focus on cultivating the students' morality (e.g., love, hard work, respect for and consideration of others), competency (e.g., information technology and skills of international communication) and social behaviors. SPS7 and SPS15 saw the latter as the "core" of citizenship education, while SPS7 and SPS15 opined that only "well-developed individuals" could promote political values.

The interview findings revealed three major strategies used by SPSs to balance this school-level emphasis on individual development with the higher authorities' demands for the promotion of political values. First, they maintained the CPC's "bottom line" when promoting the students' individual development by insisting that citizenship education reflect "CPC- and government-prescribed values." Second, the SPSs adopted government strategies for publicizing political ideology to promote student development, for example, using school flag-raising ceremonies to advocate better behavior and respect for classmates and teachers rather than focusing on "boring political ideologies." SPS13 and SPS7 referred to this as "bridging the higher authorities' requirements with students' cognitive level." Third, to foster the students' individual development, the SPSs strongly supported school-based programs and activities that reflected "students' interests and developmental needs," even going so far as promoting some political education activities for this purpose.

\subsubsection{Preference for enhancing academic achievement over citizenship education}

The SPSs involved in this study indicated their preference for pursuing academic achievement over citizenship education, calling it the "school's life blood" (SPS14). According to SPS1 and SPS8, their work on citizenship education centered on improving the students' academic performance, even though this was normally their principals' responsibility. To this end, the SPSs emphasized behavioral norms in their citizenship education leadership, since good student behavior created "a sound instructional environment" (SPS9).

The SPSs also tried to minimize citizenship education's disruption of academic instruction in three ways: having students take turns participating in extracurricular citizenship education activities; concentrating citizenship education on lower grade levels to allow older students to focus on academics; and allowing teachers to address some requirements during their free time rather than in class, to ensure "more time for instruction" while still "satisfying government demands" (SPS6).

\subsection{SPSs as both partners and contenders of school principals}

The third pattern in the SPSs' leadership in citizenship education relates to their cooperation and contention with principals. Although SPSs and principals were de facto equals and cooperated to complete citizenship education tasks, they nonetheless competed for power over the subject. 
Responding SPSs closely cooperated with their principals in two main ways. First, the SPSs established a favorable ideological environment for citizenship education (through flag raisings, etc.) to encourage expected student behavior, freeing principals from "trivial" duties and allowing them to focus on "keeping the school in line with the CPC's socialist direction" (SPS1).

Second, the SPSs who were also DPCEs reported to their principals on citizenship education matters (regardless of whether the principals could provide useful suggestions, comments or assistance) and assisted principals in citizenship education work. Specifically, the SPSs interviewed planned schoolbased citizenship education lessons and extracurricular activities to reflect the principals' ideas as part of their leadership process. They also enhanced the staff's citizenship education competence (especially HCEDs, heads of grade and class teachers), coordinated with other departments to develop collaborative citizenship education activities, conducted ideological education for all students, and dealt with student problems. In addition, they acted with respect and consideration; for instance, when seeking her principal's input, SPS8 would typically offer strategy options "rather than making [P8] go to the trouble of creating his own." This aspect, according to SPS7 and SPS13, was reflected in the SPSs' efforts to highlight the principals' role as the school's chief citizenship education leader.

However, the SPSs also struggled with their principals over the power to lead citizenship education, both conceptually and in practice. SPS2 and SPS6 both complained that their power over citizenship education was "inhibited by their principals," who could "autocratically develop, assign or reduce other school leaders' leadership responsibilities." SPS6, who was not a DPCE, complained of having less power than his principal to direct subordinates in citizenship education, while SPS2, despite being a DPCE, felt that his power over citizenship education had been "usurped" by P2, who compelled his assistance in such "trivial" matters as school safety and student order.

Many of the SPSs interviewed (e.g., SPS2, SPS15 and SPS19) employed three main strategies to gain authority over citizenship education. First, they organized informal groups that inhibited their principal's power, showcased their own work achievements and enhanced their prestige. Second, as co-leaders equal to principals, they agitated for additional citizenship education instructional time and resources. Third, they cultivated the help and support of both external and internal stakeholders. SPS1, SPS2 and SPS7, for example, used their government-assigned authority to oversee their principals and relied on the government to restrict their principal's power through policies (such as the " $1+3$ Policies of Principal Responsibility System"), breaches of which would "be reported to higher education authorities" (SPS2). In addition, the SPSs made use of SPS-led teachers' congresses to oversee their principals and force them to make decisions with regard for their subordinates' opinions.

The SPSs who were also principals were spared this competition and thus used their dualistic position to be true leaders in developing citizenship education by "[exercising] more power" to develop citizenship education curricula, organize citizenship education activities and mobilize their party and administrative subordinates to advance citizenship education (SPS5 and SPS15). At the same time, however, their administrative responsibilities reduced their direct attention to and involvement in citizenship education and other political work on campus. SPS11 and SPS15, both of whom were also principals, admitted that filling both positions meant that they "spent less time on citizenship education" because they were "busy dealing with all school-related internal and external affairs," and therefore focused on academic instruction to satisfy parent and government demands. 


\section{Discussion: Possible explanations for the SPSs' leadership patterns}

This paper now turns to some possible explanations for the complexities of the SPSs' leadership in citizenship education and political work, based on data from the interview findings and documentary analysis. This section argues that these patterns resulted from the macro- and micro-political interplay between stakeholders with different expectations of and interests in the promotion of citizenship education. This can be seen in three related elements: the structural integration between education and politics; challenges to the SPSs' leadership; and the school leaders' individual factors (e.g., personality, gender, experience, etc.). The first element relates more to school macro-politics and the latter two to micro-politics.

\subsection{Structural integration between education and politics}

The complicated relationships between the SPSs and external and internal school stakeholders are largely shaped by the CPC's efforts to control education through the institutional integration of education and politics, which can be seen in its macro-political control over the school leadership system, school leaders' career paths, and citizenship education. This has led to the SPSs' dilemma between satisfying macro-political requirements and exercising professional autonomy, as well as the ambiguous division of power and labor between SPSs and principals in school administration and citizenship education.

The first aspect of this institutional integration concerns the establishment of an administrative hierarchy in which political and administrative leaders (SPSs and principals) share the same rank, and share responsibility for ensuring that their school reflects prescribed socialist values and for cultivating socialist constructors and successors for China's development. While SPSs must be CPC members, party membership is optional for principals; however, 11 of the 13 principals interviewed in this study were CPC members. To further the amalgamation of administration and politics, SPSs and principals often occupy administrative and political leadership posts simultaneously. Principals with CPC membership frequently acted as deputy SPSs (e.g., P3) or even SPSs (e.g., P15), and SPSs were often deputy principals with administrative portfolios for citizenship education (e.g., SPS1). Moreover, although the CYL and YPC at all the subject schools were directly led by the SPSs, these political units were administered by the HCEDs (and thus were within the principal's purview) in both the schools' political and administrative lines.

The second aspect is the three-stage control the CPC-led state exercises over school leaders' career paths. First, the CPC controls the appointment of principals and SPSs. According to most interviewees, district education bureaus in Shanghai generally control the selection and appointment of principals to ensure that they serve the school's political needs. These authorities also control the selection of SPSs, although to a slightly lesser extent, as they can be elected initially by school staff members with CPC membership. As a result, SPSs and principals cannot choose their partners; for example, SPSs "could not choose to work only with principals whom they liked and with whom they got along" (SPS12), and if the two were incompatible "the two leaders would not cooperate well" (SPS19). Despite this situation, district education bureaus seldom change personnel arrangements once appointments are made (Zhang 2004). Second, both SPSs and principals must take pre- and in-service political training by participating in seminars on political principles and values; national plans, needs, conditions and developments; and ad hoc national issues. Furthermore, attendance at these seminars is one criterion used by district education bureaus to appraise school leaders. Third, the state monitors the school leaders' work, both administrative and in citizenship education, through annual evaluations, with particular attention to their 
moral standards (de), administrative abilities (zheng), diligence (qin), achievements (ji) and probity (lianjie). These appraisals have summative personnel implications for the school leaders' leadership careers, particularly their prospects for promotion.

The third aspect of the integration of education and politics concerns the CPC's control over citizenship education, which is basically political in nature. As presented above, the relative power and responsibility SPSs and principals enjoy over citizenship education is not very clear. Although responsible for formal and informal citizenship education curricula, both must ensure that their school work follows the CPC's socialist political direction (Ministry of Education 1998), and that citizenship education reflects the leadership of the CPC and is guided by Chinese socialism. As such, formal and informal citizenship curricula cover mainly Chinese socialism, patriotism, collectivism and China's current developments (Communist Party of China Central Committee 1986). Although morality and behavioral norms are included, they are largely used to cultivate the students' patriotism and love of socialism and to pave the way for the preparation and recruitment of future CPC members (State Education Commission 1995). This partly explains why SPSs and principals must cooperate to achieve their CPC-prescribed goals and duties.

\subsection{Challenges confronting the SPSs' leadership}

The leadership concerns and practices of SPSs in citizenship education and school administration are also shaped by macro- and micro-political challenges, including societal demands, parental expectations, tensions between state control and professional autonomy, and disparities in leadership status. The first two are challenges on which SPSs and principals commonly cooperate, whereas the latter two apply mainly to SPSs and involve their competition with principals for power.

Like their principals, all of the SPSs interviewed faced societal demands that affected both their school's image and their personal career. Their most commonly cited concern was the need to improve students' moral standards and social behaviors, both of which were perceived to have declined following China's 1978 economic reforms and opening to the world. Because the promotion of good behavior and social norms help schools "keep order and facilitate instruction" (SPS15), it was often seen by parents and society as an indicator of a school's quality and leadership. Thus, the issue was of common concern to both SPSs and principals and was an important area for cooperation, particularly in citizenship education.

The SPSs and principals interviewed also faced demands regarding students' academic performance, as many parents "valued academic performance above the cultivation of healthy values" (SPS11). SPS12 noted that some parents even asked school teachers to teach their children techniques for obtaining higher scores on internal and public examinations. Examination scores, as SPS11 and SPS19 further expounded, were seen by parents and higher authorities as "key criteria" for assessing school performance and the quality and performance of school leaders, including SPSs. In other words, improved student examination scores could produce "quick effects" that would benefit both the school and its leaders (SPS7, SPS11). Although the students' academic performance was primarily the responsibility of principals, SPS2 and SPS3 both asserted, in separate interviews, that they were more than willing to assist and cooperate with them in this area.

Moreover, the SPSs interviewed were caught between tight state control and a desire to exercise professional autonomy in school leadership and citizenship education. To resist the former, SPSs exercised their limited autonomy to (re)interpret and implement government policy in ways that would benefit their school, based on their professional assessment or societal demands. Although SPSs could 
broaden the scope and contents of citizenship education in response to societal demands, their professional autonomy was not unlimited. As both SPS5 and SPS7 cautiously remarked, SPSs had to adhere to the CPC's political "bottom line" (i.e., uphold CPC leadership and socialism) or risk losing their job.

Finally, the SPSs interviewed were challenged by their lack of a clear professional identity and by not having the same status as school leaders that was enjoyed by principals. Underlying the complex relationships between SPSs and principals was the fact that, to varying degrees, all the SPSs interviewed were uncomfortable with their professional identity in the complicated PRS, except for those who were also principals (e.g., SPS5, SPS11 and SPS15). Although they were equivalent to their principals and were the CPC's school-level representatives, the SPSs enjoyed relatively less power, which led the staff to see the principal as the "real" head of the school. Administratively, the SPSs, especially those who were deputy principals in charge of citizenship education, answered directly to their principals. This sense of discomfort was further reinforced by how other staff members perceived the SPSs' role and function in the leadership system. For example, the subordinates who directly assisted their SPSs in citizenship education (e.g., HCED1, DPCE10 and DPCE20) saw them more as their principals' "assistants" or "strategists" and therefore considered them less important. In practice, according to HCED2, many subordinates more often "sought advice... [about their] work on citizenship education from the principal than from the school party secretary." This partly explains why the SPSs interviewed sought to match their perceived leadership status with their actual professional rank in the school by using various strategies (identified above) to solicit support from higher authorities and to compete for power with their principals, even in the formal citizenship education curriculum, which was the latter's domain.

\subsection{Individual factors of school leaders}

The dynamic interactions between SPSs and principals in leading citizenship education and general school administration were also affected by each party's personality, gender and leadership experience. The interplay of these individual factors shaped the SPSs' attitudes and strategies toward their principals, as well as their power distribution.

In her interview, SPS19 emphasized that how well the personalities of the two heads matched largely "determine[d] whether they could work and unite closely" and therefore could have "great impacts on the overall strength of the school leadership." She further observed that "more conflicts between the SPS and principal would arise" if either felt "they were better than their partner." Most of the SPSs interviewed (e.g., SPS6, SPS8 and SPS15) agreed that it was easier to cooperate with a principal if their personalities were "complementary," particularly if the SPS was "modest" and the principal was "strong." As SPS8 explained, modesty could facilitate citizenship education by "reducing [SPSs] conflicts with principals" and "gaining [the] trust and support" (jiao xin) of the teaching staff, while strength - such as being resolute and dominant - could help principals "establish their authority as school decision-makers" and "facilitate the implementation of their decisions."

Moreover, the dynamics of the SPSs' and principals' interactions in school administration and their citizenship education leadership was influenced by gender. In this study, there were three types of SPS/principal gender pairings. The first type featured a female SPS and a male principal (e.g., Schools1, 3 and 7). This gender combination, according to two female SPSs (SPS15 and SPS19), facilitated a "more cooperative [leadership] partnership" than other gender combinations, because the two could "cooperate by playing the roles of mother and father in a family, respectively." This view was shared by other female 
SPS respondents (e.g., SPS1, SPS12 and SPS13), all of whom "highly respected" the leadership of their male principals.

The second gender combination featured SPSs and principals who were both female (e.g., Schools 4 and 9), and they tended to compete with each other for dominance. In her interview, SPS15, who was also a principal, reflected on the level of cooperation she had experienced with female ex-principals in the past, and shared that she felt the need "to struggle for more power" over the allocation of resources to citizenship education, for example. In separate interviews, SPS4 and P4 recounted competing to have their contributions recognized and to establish leadership in citizenship education. A similar situation was described by SPS9 and P9, also in separate interviews.

The third type of gender combination concerned a male SPS and a female principal (e.g., Schools 2 and 6). Some male SPSs interviewed (e.g., SPS2 and SPS6) explicitly complained about the strong leadership exercised by their female principals and criticized them for "having most power" over citizenship education and political work on campus.

The working relationships and power distribution between SPSs and principals was further complicated by their different levels of leadership ability and professional experience in three major, related ways. First, the SPSs who had served longer than their principals at a given school were afforded more respect by the latter. For instance, SPS8 and SPS13 had worked six and eight years longer, respectively, at their schools than their principals had; as a result, their principals often asked their "advice" and relied on their "support" in decision-making, because the SPSs knew "more about [the] school situation" and had "stronger interpersonal relationship[s] with other staff."

Second, the SPSs who had citizenship education leadership experience (as HCEDs or DPCEs) prior to being promoted had "more say" in citizenship education policymaking and decisions than SPSs without such experience, as P2 indirectly admitted when interviewed.

Third, differences in overall professional experience between SPSs and principals influenced the support they received from their subordinates and affected their leadership in citizenship education. According to SPS19, SPSs could garner greater staff support than their principals by fostering stronger relationships with higher authorities (e.g., inviting education officials to visit their schools) and by having more extensive professional experience (such as conducting school-based research and/or publishing academic papers, both of which were criteria for teacher promotion). Moreover, some of the school leaders interviewed (e.g., SPS8 and P16) asserted that teachers more often listened to and obeyed principals than SPSs, as the latter were seen as being "less competent" or as having less "knowledge, skill and vision of teaching, and leadership in citizenship education and school administration." They further expressed that teachers tended to seek advice from principals rather than from SPSs, even on matters of citizenship education. Schools 2 and 4 provided useful examples of how principals made use of their passion for and their expertise in their teaching areas to develop school-based citizenship education curricula. The principal of School 2 (P2) established an in-school psychological education center and integrated its activities with citizenship education, while the principal of School 4 (P4) gave that school's citizenship education curriculum a greater focus on artistic and aesthetic themes, utilizing music and art lessons to teach the importance of ethnic solidarity and unity.

To varying extents, these individual factors, compounded by challenges to their leadership, shaped the SPSs' responses to leadership concerns and behaviors when dealing with school micro- and macropolitics. They also affected the SPSs working relationships with higher authorities, principals and parents, as well as how they perceived their professional identity and leadership status. 
This study supports the view of Remy and Wagstaff (1982), that school leaders can exercise leadership in citizenship education, and Kennedy's (1997) view that education has struggled to balance the promotion of societal development and fostering political quality in its cultivation of citizens. Using Lashway's (2006) micro- and macro-political analytical framework, this study has demonstrated, through empirical evidence, that the SPSs' complex relationships and interactions with other school stakeholders in leading citizenship education are political in nature. As such, school leaders can actively use their influence and resources to lead citizenship education, resist other school leaders' (at times contradictory) responsibilities, and interact with and mediate between the interests of various actors at the macro- and micro-political levels in response to political, economic and social needs. The study also offers three major interrelated theoretical implications for understanding school leadership and citizenship education.

The first theoretical implication concerns school leaders exercising their professional autonomy to manage the expectations and interplay of diverse interest groups. This study supports Law's (2009, 2012) view that school leaders are active agents in responding to the state, and challenges Child's (1994) view that school leaders are passively controlled by the CPC-led state. In this case, though both the macroand micro-political actors considered transmitting political values and promoting students' individual development necessary to citizenship education, the macro-political actors (e.g., the state) demonstrated a passion for the former, while the micro-political actors (e.g., parents and the community) were more interested in the latter. The macro- and micro-political actors interacted with each other and exercised intertwined influences on citizenship education's position in the curriculum and the school leaders' work. The SPSs interviewed, as major leaders of citizenship education, had to exercise their professional autonomy to balance diverse interests. They also adjusted the contents and strategies of citizenship education, while still maintaining the CPC-led state's bottom line and remaining within the CPC's political framework.

The second theoretical implication is that cooperation and struggles coexist in principals' and SPSs' dual leadership of citizenship education. This challenges the findings of other China studies, which hold that the relationship between SPSs and principals is characterized either by consensus and cooperation (Tao et al. 1988) or by power struggles (Lin 2000). On the one hand, SPSs and principals cooperate to satisfy the CPC-led state's twin expectations - that academic quality be improved for economic development purposes and that citizenship education reflect and serve the CPC's political objectives. Their cooperation was mainly characterized by the SPSs' assisting the more dominant principals, who were responsible for the schools' overall academic excellence and citizenship education. On the other hand, SPSs and principals compete for power at the school level; as school political leaders in charge of school ideological work, the SPSs competed with their principals for power over citizenship education and to highlight the importance of their work in citizenship education.

The third and final theoretical implication concerns the dynamics of citizenship education leadership. The findings of this study have shown that cooperation and contention among macro- and micro-political actors was not stable but instead shifted depending on the situation. In addition, they involved the parties' interests, which supports Lashway's (2006) viewpoint that micro-political actors can unite in response to macro-political actors, or ally with macro-political actors against micro-political actors whose needs or views differ from their own. As this article has demonstrated, on the one hand, the SPSs did cooperate with their principals when both were aligned against the government; on the other hand, the SPSs supported the government's agenda by soliciting support from subordinates to constrain their principals' power, even though their competition was challenged from both within and outside of the school, and 
despite differences in individual factors such as leadership and professional experiences. In other words, as in general school leadership, cooperation in and conflict over school leadership in citizenship education can coexist between different stakeholders to varying extents, depending on the chemistry of their interests and the availability of power (Blase and Anderson 1995).

\section{Conclusion}

With specific reference to China, this study has explored the complex leadership of SPSs as agents of the state in citizenship education. Specifically, it has examined, from macro- and micro-political theoretical perspectives, the interactions between and among SPSs, macro-political actors (e.g., the state) and micro-political actors (e.g., principals, other school leaders, teachers, students and parents). It has shown that the SPSs' leadership in citizenship education involves both their mediation between macroand micro-political actors' needs and their cooperation and competition with their principals. These can be interpreted as resulting from the CPC-led state's strategy of integrating politics and education, multiple social and school challenges confronting the SPSs leadership and the SPSs' individual factors.

To interpret these findings, this study has proposed a framework for understanding school leadership in citizenship education as a political exercise. This framework shows that school leadership in citizenship education involves the school leaders' use of influence and resources, interacting with various actors at the macro- and micro-political levels and mediating between those actors' diverse expectations and interests. This framework is useful for explaining how school leadership in citizenship education in China can be shaped by the dynamic, complex and intertwined relationships between schools' microand macro-political actors, who have different interests and use different resources to further their interests.

This qualitative study has a number of limitations: it gathered data from only a small number of subject school leaders, schools and cities; it focused on school leadership in junior secondary schools only; and the data provided by its interviewees were mainly self-reported. Thus, this study might not necessarily reflect actual and full daily leadership concerns and practices. Because of these limitations, this study has no intention of generalizing its findings to include school leaders in other schools in Shanghai and elsewhere in China. Future research could be done by shadowing SPSs to provide a deeper and more holistic picture of their leadership; examining the SPSs' leadership in citizenship education in junior secondary schools in other areas of China; and, investigating and comparing the dynamics and complexities of leadership in citizenship education in primary and senior secondary schools. Scholars could also conduct research on the SPSs' leadership style, as well as the role of the citizenship education in regulating students' and teachers' behaviors.

\section{Acknowledgement}

The authors would like to express their heartfelt gratitude to all the school leaders and staff who participated in this study and to those who helped us to contact the schools used in this study.

\section{References}

Banks, J. A. (2008). Diversity, group identity, and citizenship education in a global age. Educational Researcher, 37(3), 129-139. 
Bao, C. (2004). Xiaozhang fuzezhixia de xiaozhang quanli daxiao jiqi guiyue [School principals' power in Principal Responsibility System and its regulation]. Jiaoyu Kexиe [Education Science], 20(4), 51-53.

Bazeley, P. (2007). Qualitative data analysis with NVivo. London: SAGE.

Blase, J., \& Anderson, G. L. (1995). The micropolitics of educational leadership: From control to empowerment. London: Cassell.

Blase, J., \& Blase, J. (2002). The micropolitics of instructional supervision: A call for research. Educational Administration Quarterly, 38(1), 6-44.

Bush, T. (2011). The micropolitics of educational change. Educational Management, Administration \& Leadership, 39(6), 642-645.

Bush, T., \& Qiang, H. (2000). Leadership and culture in Chinese education. Asia Pacific Journal of Education, 20(2), 58-67.

Chen, G. (2003). Xuexiao guanli tizhi wenti yinlun [Discussion on school aministration system]. Huadong Shifan Daxue Xuebao (Jiaoyu Kexueban) [Journal of East China Normal University (Education Science)], 21(1), 1-6.

Cheung, K. W., \& Pan, S. Y. (2006). Transition of moral education in China: Towards regulated individualism. Citizenship Teaching and Learning, 2(2), 37-50.

Child, J. (1994). Management in China during the age of reform. Cambridge [England]: Cambridge University Press.

Communist Party of China Central Committee (1985). Reform of China's educational structure. Beijing: Foreign Languages Press.

Communist Party of China Central Committee (1986). Guanyu shehuizhuyi jingshen wenming jianshe zhidao fangzhen de jueyi [Decision on the guideline of socialist spiritual civilization]. In D. He (Ed.), Zhonghua renmin gongheguo zhongyao jiaoyu wenxian (1976-1990) [The important educational documents in People's Republic of China (1976-1990)] (pp. 2504-2505). Haikou: Hainan Press.

Datnow, A. (2000). Power and politics in the adoption of school reform models. Educational Evaluation and Policy Analysis, 22(4), 357-374.

Dimmock, C., \& Walker, A. (2002). School leadership in context--societal and organizational cultures. In T. Bush, \& L. Bell (Eds.), The principles and practice of educational management (pp. 7085). London: Paul Chapman.

Hallinger, P., \& Muppy, J. F. (1986). The social context of effective schools. American Journal of Education, 94(3), 328-355.

Hoy, W. K., \& Miskel, C. G. (2004). Educational administration, policy, and reform: Research and measurement. Greenwich: Information Age Pub.

Hoyle, E. (1999). The two faces of micropolitics. School Leadership \& Management, 19(2), 213 - 222.

Jiao, X. (2012, December 25). Yiwu jiaoyu xiaozhang zhijizhi youwang tuixing [Principal Responsibility System in basic education can hopefully be implemented]. Zhongguo Jiaoyubao [China Education Daily].

Jin, Z. (2001, January 16). Shanghai quanmian tuixing zhongxiaoxue xiaozhang zhijizhi [Shanghai fully implement principal professional ranking system]. Zhongguo Jiaoyubao [China Education Daily].

Kennedy, K. J. (Ed.). (1997). Citizenship education and the modern state. London: Falmer Press. 
Kennedy, K. J., Lee, W. O., \& Grossman, D. L. (Eds.). (2010). Citizenship pedagogies in Asia and the Pacific. Hong Kong: Comparative Education Research Centre, University of Hong Kong.

Kerr, D. (1999). Citizenship education in the curriculum: An international review. The School field, $X(3 / 4), 5-32$.

Kubow, P. K., Grossman, D., \& Ninomiya, A. (1998). Multidimensional citizenship: Educational policy for the 21st century. In J. J. Cogan, \& R. Derricott (Eds.), Citizenship for the 21st century: An international perspective on education (pp. 115-134). London: Kogan Page.

Lashway, L. (2006). Political leadership. In S. C. Smith, \& P. K. Piele (Eds.), School leadership: Handbook for excellence in student learning (pp. 266-281). Thousand Oaks, Calif.: Corwin Press.

Law, W. W. (2006). Citizenship, citizenship education and the state in China in a global age. Cambridge Journal of Education, 36(4), 597-628.

Law, W. W. (2009). Culture and school leadership in China: Exploring school leaders' views of relationship- and rule- based governance. In A. W. Wiseman (Ed.), Global contexts and international comparions (pp. 303-341). Bingley: Emerald Publishing.

Law, W. W. (2012). Educational leadership and culture in China: Dichotomies between Chinese and Anglo-American leadership traditions? International Journal of Educational Development, 32(2), 273-282.

Lee, W. O. (1997). Changing ideopolitical emphases in moral education in China: An analysis of the CCP Central Committee documents. In W. O. Lee, \& M. Bray (Eds.), Education and political transition: Perspectives and dimensions in East Asia (pp. 99-114). Hong Kong: Comparative Education Research Centre, The University of Hong Kong.

Lee, W. O., \& Gu, R. (Eds.). (2004). Guoji shiye yu gongmin jiaoyu: Xianggang ji Shanghai zhongxue zhuangkuang diaocha [Global citizenship education: A survey on secondary schools in Hong Kong and Shanghai]. Shanghai: Shanghai Academy of Social Sciences Press.

Lee, W. O., \& Ho, C. H. (2005). Ideopolitical shifts and changes in moral education policy in China. Journal of Moral Education, 34(4), 413-431.

Li, G., \& Wang, B. (2000). Zhongguo jiaoyu zhidu tongshi (1949-1999) [The history of Chinese educational policy (1949-1999)]. Jinan: Shandong Education Press.

Lin, J. (1993). Education in post-Mao China. Westport: Praeger.

Lin, J. (2000). Reform in primary and secondary school administration in China. In C. Dimmock, \& A. Walker (Eds.), Future school administration: Western and Asian perspectives (pp. 291-309). Hong Kong: Chinese University Press.

Merriam, S. B. (1998). Qualitative research and case study applications in education (2nd ed.). San Francisco, Calif.: Jossey-Bass Publishers.

Ministry of Education (1998). Zhongxiaoxue deyu gongzuo guicheng [Regulations of primary and secondary school moral education]. http://www.moe.edu.cn/edoas/website18/33/info5933.htm. Accessed March 12010.

Osler, A., \& Starkey, H. (2003). Learning for cosmopolitan citizenship: Theoretical debates and young people's experiences. Education Review, 55(5), 243-254.

Pike, M. A. (2007). Values and visibility: The implementation and assessment of citizenship education in schools. Educational Review, 59(2), 215-229.

Remy, R. C., \& Wagstaff, L. H. (1982). Principals can exert a leadership role in citizenship education. NASSP Bulletin, 66(454), 55-62. 
Shanghai Municipal Education Commission (2003). Shanghaishi zhongxiaoxue dangzhibushuji duiying xiaozhang zhiji biaozhun pingding fangan [The plan that corresponding to principal prosessional level for assessing party secretary in primary and secondary school in Shanghai municipal]. http://www.shmec.gov.cn/html/xxgk/200310/4060420040002.php. Accessed January 272013.

Smith, S. C., \& Piele, P. K. (2006). School leadership: Handbook for excellence in student learning (4th ed.). Thousand Oaks, Calif.: Corwin Press.

State Education Commission (1990). Guanyu kaizhan zhongxiaoxue xiaozhang gangwei peixun de ruogan yijian [Guidance on principals' training]. In D. He (Ed.), Zhonghua renmin gongheguo zhongyao jiaoyu wenxian (1976-1990) [The important educational documents in People's Republic of China (1976-1990)] (pp. 3000-3002). Haikou: Hainan Press.

State Education Commission (1995). Zhongxue deyu dagang [The outline of secondary school moral education]. In D. He (Ed.), Zhonghua renmin gongheguo zhongyao jiaoyu wenxian (1991-1997) [The important educational documents in People's Republic of China (1991-1997)] (pp. 37783782). Haikou: Hainan Press.

Sun, C., Tao, G., Qiu, Z., Li, R., \& Chen, X. (1988). Jianchi shiyan, jiji tansuo, zhubu shenru, buduan wanshan: Shanghaishi "xiaozhang fuzezhi" shidian qingkuang diaocha [Persistent experiment, active exploration, gradual penetrantion and continuing improvement: The investigation on the experiment of "Principal Responsibility System" in Shanghai]. Shanghai Jiaoyu Keyan [Shanghai Research on Education], 4, 32-35.

Tao, Z., Liu, G., \& Yi, X. (1988). Tantan zhongxue de dangzheng fenkai wenti [On the separtation of administrative power and party power in middle schools]. Renmin Jiaoyu [People's Education], 6, 19-20.

Teng, T. (1988). Zai quanguo zhongxiaoxue deyu gongzuo huiyishang de baogao [Remarks addressed at the national education conference]. In D. He (Ed.), Zhonghua renmin gongheguo zhongyao jiaoyu wenxian (1976-1990) [The important educational documents in People's Republic of China (1976-1990)] (pp. 2759-2761). Haikou: Hainan Press.

Walker, A., \& Dimmock, C. (2002). Cross-cultural and comparative insights into educational administration and leadership. In A. Walker, \& C. A. J. Dimmock (Eds.), School leadership and administration: Adopting a cultural perspective. New York: Routledge Falmer.

Wiersma, W. (2005). Research methods in education: An introduction (8th ed.). Boston: Pearson/Allyn and Bacon.

Wong, K. C. (2005). Conditions and practices of successful principalship in Shanghai. Journal of Educational Administration, 43(6), 552-562.

Xiao, Z. (1984). Zhongxiaoxue neibu de lingdao tizhi yingdang gaige [Primary and secondary school leadership system should be reformed]. Renmin Jiaoyu [People's Education], 9, 16-17.

Xiao, Z. (2000). Xiaozhang fuzezhi de tichu ji neihan [The proposition and meaning of Principal Responsibility System]. Zhongxiaoxue Guanli [Primary and Secondary School Administration], 11, 2-5.

Zhang, L. (2004). Xuexiao zuzhi de duoyuan maodun ji dui xiaozhang fuzezhi shishi de yingxiang [The schol multiple contradictions and influences on the implementation of Principal Responsibility System]. Jiaoxue Yu Guanli [Journal Teaching and Management], 7(5), $72-76$. 
Zhang, Z. (2006). Xiaozhang fuzezhi: Fazhan licheng yu wenti pouxi [Principal Responsibility System: History and problems]. Zhongxiaoxue Guanli [Journal of Primary and Secondary School Administration], 10, 11-14.

Zhao, Z., \& Fairbrother, G. P. (2010). Pedagogies of cultural integration in Chinese citizenship education. In K. J. Kennedy, W. O. Lee, \& D. L. Grossman (Eds.), Citizenship pedagogies in Asia and the Pacific (pp. 37-52). Hong Kong: Comparative Education Research Centre, The University of Hong Kong.

Zhong, M., \& Lee, W. O. (2008). Citizenship curriculum in China: A shifting discourse towards Chinese democracy, law education and psychological health. In D. L. Grossman, W. O. Lee, \& K. J. Kennedy (Eds.), Citizenship curriculum in Asia and the Pacific (pp. 61-73): Springer Netherlands.

Zhu, X., \& Feng, X. (2008). On the development of citizenship education outlook in China. Frontiers of Education in China, 3(1), 1-21. 